\section{DIGITAL COMMONS \\ @ UNIVERSITY OF SOUTH FLORIDA}

\section{ABO: Interactive Journal for Women in the Arts, 1640-1830}

Volume 5

Issue 2 Volume 5.2 (Fall 2015)

Article 4

2015

\title{
The Dale Spender Collection at the Women's College, University of Sydney
}

Olivia Murphy

University of Sydney, olivia.murphy@sydney.edu.au

Follow this and additional works at: https://digitalcommons.usf.edu/abo

Part of the Australian Studies Commons, Literature in English, Anglophone outside British Isles and North America Commons, Literature in English, British Isles Commons, Other Feminist, Gender, and Sexuality Studies Commons, and the Women's Studies Commons

\section{Recommended Citation}

Murphy, Olivia (2015) "The Dale Spender Collection at the Women's College, University of Sydney," ABO: Interactive Journal for Women in the Arts, 1640-1830: Vol.5: Iss.2, Article 4.

http://dx.doi.org/10.5038/2157-7129.5.2.4

Available at: https://digitalcommons.usf.edu/abo/vol5/iss2/4

This Notes and Discoveries is brought to you for free and open access by Digital Commons @ University of South Florida. It has been accepted for inclusion in ABO: Interactive Journal for Women in the Arts, 1640-1830 by an authorized administrator of Digital Commons @ University of South Florida. For more information, please contact digitalcommons@usf.edu. 


\title{
The Dale Spender Collection at the Women's College, University of Sydney
}

\author{
Abstract \\ Notice of the opening of the Dale Spender collection of books relating to feminism; Australian women's \\ writing; and women's writing in English of the long nineteenth century.
}

\section{Keywords}

Dale Spender, feminism, women's writing, nineteenth-century novel

Creative Commons License

(c) (1) $\odot$

This work is licensed under a Creative Commons Attribution-No Derivative Works 3.0 License. 
The library of the Women's College within the University of Sydney wishes to announce the opening of the Dale Spender Collection to interested scholars. Dale Spender-pioneering feminist and author of Man Made Language (1980), Scribbling Sisters (1984), and Mothers of the Novel: 100 Good Women Writers before Jane Austen (1986), among many other works - was also the series editor of Pandora Press. Dr. Spender's efforts to 'rediscover' and popularize women's writing, especially that of the seventeenth and eighteenth centuries, has contributed immeasurably to the development of the discipline in the last thirty years.

Dr. Spender has made the generous donation of her personal collection to the College. The collection includes: (1) feminist theory and political writing, especially 1970-1990; (2) Australian women's literature of the late twentieth century; (3) twentieth-century women's fiction in English; and (4) late twentieth-century editions of eighteenth-century and other women's writing. Perhaps of greatest interest to $A B O$ readers, however, are the first and early editions of early nineteenth-century fiction, with writers such as Mary Brunton, Frances Burney, Maria Edgeworth and Elizabeth Hamilton represented. In addition, the collection also includes works by later Victorian novelists including Mary Elizabeth Braddon, Rhoda Broughton, Mary Cholmondeley, Frances Power Cobbe, Dinah Craik, Sarah Grand, Mary Howitt, Margaret Wolfe Hungerford, E. Lynn Linton, Margaret Oliphant, Ouida [Maria Louise Ramé], Rita [E.M. Gollan], Elizabeth Robins, Adeline Sergeant, Charlotte M. Yonge, and many others.

For information about the Spender Collection please contact:

The Women's College

The University of Sydney

NSW 2006, Australia.

reception@thewomenscollege.com.au

https://www.thewomenscollege.com.au/index.php 